\title{
Pesantren dan Upaya Menangkal Tumbuhnya Radikalisme: Analisis Gagasan KH. Marzuki Mustamar
}

\author{
Mohamad Salik', Ali Mas'ud ${ }^{\text {b) }}$ \\ a) UIN Sunan Ampel Surabaya \\ b) UIN Sunan Ampel Surabaya
}

\section{ABSTRAK}

Studi ini bertujuan untuk meneliti gagasan-gagasan seorang tokoh terkemuka Nahdlatul Ulama (NU), pimpinan Pondok Pesantren Sabilurrosyad Malang yaitu KH Marzuki Mustamar tentang upaya menangkal tumbuhnya paham radikalisme pada pondok pesantren. Melalui analisa hasil wawancara, penelitian ini menemukan bahwa yang terpenting dalam upaya menangkal tumbuhnya paham radikalisme di pesantren adalah kemampuan para kyai atau pengasuh pesantren dalam mengontekstualisasikan nilai-nilai ajaran Islam dengan konteks kehidupan yang ada dalam proses pembelajarannya. Melalui kemampuan ini, para santri akan menjadi tahu dan memahami bahwa ajaran Islam benar-benar relevan dengan kehidupan dan mampu membawa kemaslahatan bagi seluruh umat manusia. Dalam hal ini, para kyai atau para pengasuh pesantren bisa melakukannya melalui beberapa cara: pertama, memilih materi-materi atau kitab-kitab yang berpandangan moderat yaitu yang berpaham ahlussunnah, dan menafsirkan ulang terhadap materi-materi atau kitab-kitab yang tidak sesuai dengan konteks keindonesiaan. Kedua menanamkan kepada para santri nilainilai ketauhidan dan nilai-nilai kemanusiaan secara seimbang, ketiga, memberikan keteladanan dalam berperilaku toleran di masyarakat. Keempat membiasakan para santri berperilaku toleran melalui praktek langsung berbaur dengan masyarakat.

\section{ABSTRACT}

This study aims to examine the ideas of one prominent Nahdlatul Ulama (NU) figure, the leader of Pesantren Sabilurrosyad Malang named KH Marzuki Mustamar, about efforts to counteract the growth of radicalism in pesantren. Through the analysis of the interview, this study found that the most important thing in preventing the growth of radicalism in pesantren is the ability of the teacher or Kyai to contextualize the values of Islamic teachings with the real context of life in the learning process. Through this ability, the students will know and understand that Islamic teachings are truly relevant to life and are able to bring benefits to all mankind. In this case, the teacher or Kyai can do in several ways: First, selecting materials or books that have moderate views based on ahlussunnah school, and reinterpreting the materials or books that are not in accordance with the Indonesian context. Second, instilling the values of monotheism and human values in the students in a balanced manner. Third, providing examples oftolerant behavior in society. Fourth, accustoming the students to be tolerant through direct practice to live in the community.
KATA KUNCI

Pesantren; Radikalisme;

Kontekstualisasi.

\section{KEYWORDS}

Pesantren; Radicalism;

Contextualization.

\section{A. Pendahuluan}

Diskursus tentang gerakan radikalisme selalu menarik dan cukup aktual untuk diperbincangkan. Hal ini seiring dengan masih merebaknya paham dan gerakan-gerakan radikal yang terjadi di berbagai wilayah bumi ini. Gerakan-gerakan tersebut tentunya sangat mengancam perdamaian dunia dan 
membahayakan bagi kelangsungan hidup umat manusia. Pada akhir-akhir ini telah banyak yang menjadi korban akibat aksi terror dan gerakan radikalisme yang terjadi berbagai belahan dunia dan mengakibatkan ratusan dan bahkan ribuan jiwa melayang. ${ }^{1} \mathrm{Di}$ Indonesia juga tidak luput dari aksi serupa. ${ }^{2}$ Salah satu di antaranya adalah penusukan terhadap salah seorang pejabat tinggi negara yaitu Menkopolhukam Wiranto oleh seorang tersangka yang merupakan bagian dari Khilafatul Muslimin yang memiliki kaitan erat dengan kelompok ISIS. ${ }^{3}$

Di Indonesia gerakan-gerakan radikalisme ini mulai menjamur sejak terbukanya kran demokratisasi pasca reformasi, setelah pada masa-masa sebelumnya mampu diredam oleh pemerintah. Diskursus ini semakin menguat karena mendapatkan respon secara internasional. Semenjak satu dasawarsa terakhir perhatian dunia disibukkan dengan isu radikalisme terutama pasca kemenangan Taliban di Afganistan, tragedi 11 september 2002, serta gerakan ISIS di Syiria dan Irak. Gerakan-gerakan keislaman tersebut sering mengusung ideologi jihad, syariat Islam, negara Islam, dan khilafah Islamiyah. ${ }^{4}$

Di antara lembaga yang mendapat sorotan tajam dari kalangan Barat atas terjadinya gerakan radikal dan terorisme tersebut adalah pondok pesantren. Lembaga ini dianggap sebagai tempat penyemaian atau the breeding grounds bagi tumbuhnya gerakan teroris. Sebagaimana ditulis oleh Robert W Hefner ${ }^{5}$ dalam sebuah bukunya, 'Since 9 September attacks in the United States and October 2002 Bali Bombings in Indonesia, Islamic Schools in Southeast Asia have been the focus of International attention. ' Hal senada juga dinyatakan oleh Martin van Bruinessen bahwa pondok pesantren terutama pondok pesantren tradisional yang berbasis `Jamaah Islamiyah` telah menjadi tempat persemaian bagi tumbuhnya gerakan radikal. ${ }^{6}$

Pandangan-pandangan negative mengenai pondok pesantren juga ditemukan dalam beberapa tulisan yang lain. Misalnya sebagaimana ditulis Timothy Mapes dengan judul Indonesian School has Chilling Rorter of Terorist Alumnidalam Wall Street Journal, 3 September 2003, Jane Parlez dalam tulisannya berjudul Saudis Quietly Promote Strict Islam in Indonesia, dimuat dalam New York Times, 5 Juli 2003, Andrew Marshal dalam tulisannya berjudul The Threat of Ja'far dimuat dalam New York Times, 10 Maret 2002. SS Misra juga menulis dalam Journal of Asian Affair dengan judul `Islamic Terorism in Indonesia . Dalam tulisannya ia menuduh bahwa pondok pesantren dan madrasah-madrasah tradisional

\footnotetext{
1 "Melawan Radikalisme", Jawa Pos (Surabaya), 24 Maret 2016, 1.

2 Http://Media.yaa.com/article/2016/01/rangkaian-teror-bom-di-indonesia-selama-15-tahun-3433485.html. diakses pada 28 Maret 2016.

3 https://news.detik.com/berita/d-4744671/jaringan-pelaku-penusukan-wiranto-terungkap-lagi, diakses 16 Maret 2020.

${ }^{4}$ Mohamad Salik, "Conserving Moderate Islam in Indonesia An Analysis of Muwafiq`s Speech on Online Media”, Journal of Indonesian Islam, Vol. 13 No. 02 (June 2019); 373-374. Lihat juga, Zuhairi Misrawi, "Dialektika Islamisme, Khilafah dan Syari’ah," dalam Komaruddin Hidayat (ed), Kontroversi Khilafah Islam, Negara dan Pancasila (Bandung: Mizan, 2014), 69-71.

${ }^{5}$ Robert W. Hefner, Making Modern Muslims; The Politics of Islamic Education in Southeast Asia (University of Hawaii Press, 2009), 1.

${ }^{6}$ Martin van Bruinessen, The Madrasa in Asia Political Activism and Transnational Linkages (Amsterdam University Press, 2008), 217.
} 
yang ada di Indonesia adalah serupa, bahwa keseluruhan madrasah yang independen dari pemerintah merupakan tempat persemaian subur untuk melatih para anak-anak miskin dan mencetak Islam radikal. $^{7}$

Pandangan di atas sebenarnya cukup beralasan karena sebagian para pelaku yang terlibat dalam aksi radikalisme dan terorisme berasal dari kalangan pondok pesantren. Sebut saja misalnya, Fathurrohman al-Ghozi yang tertangkap di Filipina karena menyimpan satu ton bahan peledak dan belasan senjata laras panjang. la adalah orang Madiun yang pernah menjadi santri pada Pondok Pesantren Al-Mukmin Ngruki. Para pelaku bom Bali yaitu Imam Amrozi, Imam Samudra, Ali Imron, Ali Ghufron, mereka adalah berasal dari pondok pesantren Al-Islam Lamongan. Demikian pula Ustadz Jafar Thalib yang sering dikaitkan dengan gerakan radikalisme agama juga berasal dari pondok pesantren, yaitu Pondok pesantren Ihya'us-Sunnah. ${ }^{8}$ Bukti-bukti tersebut seakan memperkuat anggapan masyarakat bahwa pondok pesantren merupakan tempat tumbuhnya benih-benih radikalisme dan terorisme.

Pondok Pesantren sebenarnya merupakan sebuah lembaga yang mengembangkan nilai-nilai keislaman dan juga mengakomodir nilai-nilai lokal ke-Indonesiaan. Hal ini sebagaimana dinyatakan oleh Abd Rahman Mas'ud bahwa pola pendidikan yang selama ini dikembangkan di pondok pesantren bersifat damai, terbuka dan moderat, di sisi lain mengembangkan budaya Islam Indonesia yang santun, teposeliro dan kekeluargaan. ${ }^{9}$ Hal senada juga dinyatakan oleh Cak Nur bahwa secara historis ajaranajaran pada pondok pesantren tidak hanya mengandung makna keislaman, tetapi juga makna keaslian Indonesia. ${ }^{10}$ Dengan demikian ajaran-ajaran yang mengandung paham radikalisme jelas bertentangan dengan nilai-nilai ajaran pada pondok pesantren.

Namun demikian dalam perkembangannya, yaitu memasuki decade awal abad 21, terdapat beberapa pesantren yang mulai berubah. Terdapat beberapa pesantren yang disinyalir memiliki paham radikal dan berpotensi ke arah radikal. Pesantren semacam ini menurut Musa Asy`ari, mengembangkan model pendidikan yang anti realitas plural, karena masih mempertahankan tradisi dengan memahami teks-teks al-Qur`an dan Hadis secara normatif tanpa melihat realitas plural. ${ }^{11}$ Paham semacam ini tentu sangat berbahaya karena bisa mengancam kelangsungan hidup dan keutuhan bangsa Indonesia.

Studi berkenaan dengan pondok pesantren dan upaya-upaya mengatasi radikalisme telah banyak dilakukan oleh para peneliti terdahulu. Di antaranya adalah penelitian yang dilakukan oleh Mu`ammar Ramadhan berjudul Deradikalisasi Agama melalui Pendidikan Multikulturalisme dan

\footnotetext{
${ }^{7}$ Sulasman, “Peaceful Jihad dan Pendidikan Deradikalisasi Agama," Jurnal Walisongo, Vol. XXIII, No. 1, (Mei 2015$), 152$.

${ }^{8}$ Mukhibat, "Deradikalisasi dan Integrasi Nilai-nilai Pluralitas dalam Kurikulum Pesantren Salafi Haraki di Indonesia, Jurnal Al Tahrir, Vol. IV, No. 1 (Mei 2014), 182.

${ }^{9}$ Abd Rahman, Masud, "Peran Ulama dalam Menjaga Persatuan, Kesatuan, dan Keutuhan NKRI" sambutan atas nama Menteri Agama di Pondok Pesantren Al-Hikam, Depok (11/6).

http://www.kemenag.go.id/index.php?a=berita\&id=267512, diakses 26 Maret 2016.

${ }^{10}$ Yasmadi, Modernisasi Pesantren (Jakarta: Ciputat Press, 2002), 62.

${ }^{11}$ Musa Asy`ari, Menggagas Revolusi Kebudayaan tanpa Kekerasan (Yogyakarta: LESFI, 2003), 20.
} 
Inklusifisme (Studi pada Pesantren al Hikmah Benda Sirampog Brebes). ${ }^{12}$ Dari tulisannya tersebut ia berkesimpulan bahwa salah satu bentuk upaya menangkal radikalisme agama adalah melalui internalisasi nilai-nilai multikultural dan inklusivisme dalam proses pembelajaran. Penulis lain Ahmad Darmaji dalam artikelnya berjudul Pondok Pesantren dan Deradikalisasi Islam di Indonesia. Dalam artikel tersebut ia berkesimpulan bahwa pada dasarnya pondok pesantren yang berkembang di Indonesia memiliki watak yang damai, namun demikian karena adanya pengaruh gerakan Islam transnasional maka pada beberapa pesantren tertentu terjadi radikalisasi terhadap pemahaman ajaran agama. Dalam mengatasi hal ini, diperlukan peran pemerintah melalui penguatan institusi Lembaga pendidikan Islam agar mampu memutus mata rantai gerakan radikalisme. ${ }^{13}$ Mukhibat menulis sebuah artikel berjudul Deradikalisasi dan Integrasi Nilai-nilai Pluralitas dalam Kurikulum Pesantren Salafi Haraki di Indonesia. Dalam tulisan tersebut ia berkesimpulan bahwa dalam upaya menangkal radikalisme, pondok pesantren perlu mengintegrasikan nilai-nilai pluralitas dalam kurikulumnya. Integrasi tersebut dilakukan melalui proses inkulturasi, yaitu dengan membuat silabus yang memuat materi tentang pluralitas. ${ }^{14}$

Dalam rangka turut mencari solusi untuk menangkal berkembangnya paham radikalisme, Tulisan ini bermaksud melakukan kajian lebih mendalam tentang upaya-upaya pesantren dalam rangka menangkal tumbuhnya paham radikalisme. Berbeda dengan studi-studi sebelumnya yang umumnya melakukan studi lapangan, penelitian ini lebih bersifat studi gagasan seorang tokoh yang tidak hanya berpengalaman mengelola pesantren, tetapi juga pejuang yang gigih dalam upayanya menangkal tumbuhnya paham radikalisme di negeri ini. Beliau adalah KH Marzuki Mustamar. Di samping sebagai pendiri dan pengasuh pondok pesantren, beliau juga dikenal sebagai seorang mubaligh yang cukup dikenal ketegasannya, menjadi ketua PWNU Jawa Timur dan akhir-akhir ini mendapatkan penghargaan dari the Founder of Vision of Peace Awards Indonesia (VPAI) yang berpusat di Amerika sebagai Duta Perdamaian Dunia (the International Peacekeeper Ambassador). ${ }^{15}$

Selanjutnya bagaimanakah gagasan-gagasan KH Marzuki berkenaan dengan upaya menangkal tumbuhnya radikalisme di pesantren? Mengenai hal ini akan diuraikan lebih lanjut melalui analisa mendalam atas hasil interview yang dilakukan peneliti pada 26 September 2019.

\section{B. Terminologi Radikalisme}

Istilah "radikalisme" berasal dari Bahasa Latin, kemudian diserap ke dalam beberapa bahasa lain. Secara etimologi istilah tersebut berasal dari kata radicalis, yang memiliki arti berkaitan dengan akar. Istilah radicalis berakar dari kata radix artinya akar.

\footnotetext{
${ }^{12}$ Muammar Ramadhan, "Deradikalisasi Agama melalui Pendidikan Multikultural dan Inklusivisme (Studi pada Pesantren al Hikmah Benda Sirampog Brebes), Smart, Vol. 01, No. 02 (Desember 2015), 188.

${ }^{13}$ Ahmad Darmaji, “Pondok Pesantren dan Deradikalisasi Islam di Indonesia," Millah, Vol. XI, No. 1 (Agustus $2011,248$.

${ }^{14}$ Mukhibat, "Deradikalisasi dan Integrasi Nilai-Nilai Pluralitas dalam Kurikulum Pesantren Salafi Haraki di Indonesia, $A$ I Tahrir, Vol. 14, No. 1 (Mei 2014), 201.

${ }^{15}$ https://www.timesindonesia.co.id/read/news/248615/peace-facilitator-of-vision-of-peace-awards-granted-to-khmarzuki-mustamar, diakses 17 Maret 2020
} 
Istilah radical atau radicalism memiliki makna sebuah perubahan atau bahwa pembaharuan itu harus berangkat dari akar utamanya, sedangkan akar yang paling dasar adalah masyarakat. ${ }^{16}$ Dalam istilah Bahasa Indonesia, istilah radikalisme adalah sebuah paham yang menginginkan sebuah perubahan atau pembaharuan yang dilakukan dengan cara yang keras, drastic hingga keakar-akarnya. ${ }^{17}$ Istilah "radikalisme" di dalam Bahasa Arab biasanya disepadankan kata at-tatharuf yang berarti berada di ujung paling jauh dari yang tengah atau bisa juga bermakna "berlebihan dalam sesuatu". Istilah ini pada mulanya digunakan untuk hal yang sederhana dan konkrit, seperti berlebihan ketika berdiri, duduk, dan berjalan. Tetapi istilah tersebut kemudian dimaknai lebih jauh untuk digunakan dalam halhal yang bersifat abstrak seperti berlebihan di dalam berfikir, berkeyakinan dan bertindak. Dari sini selanjutnya muncul istilah-istilah baru seperti radikalisme dalam keberagamaan dan lain sebagainya. ${ }^{18}$

Secara terminologi, berbagai pendapat dikemukakan oleh banyak tokoh berkenaan dengan pengertian radikalisme. Mukhibat dalam sebuah artikelnya menjelaskan bahwa radikalisme adalah sikap fanatik yang berlebihan terhadap pemikiran atau pandangan tertentu dengan mengabaikan pandangan atau pendapat orang lain, tanpa mempertimbangkan faktor-faktor sejarah, konteks, dan hanya memahami teks secara tekstual saja sehingga pandangannya tidak sesuai dengan tujuan dari diturunkannya syari at Islam. ${ }^{19}$

Sementara menurut Zuly Qodir, ${ }^{20}$ radikalisme adalah paham yang menginginkan adanya perubahan secara total terhadap tatanan-tatanan yang berlaku pada sebuah masyarakat. Ditinjau dari sudut politik, radikalisme merupakan sebuah paham yang meyakini bahwa sebuah masyarakat itu harus diubah secara revolusioner, tanpa adanya upaya seperti itu maka perubahan tidak akan pernah bisa terwujud. Berdasarkan pandangan-pandangan di atas maka paham atau gerakan radikalisme cenderung mengedepankan kekerasan dan bahkan tidak jarang dari tindakannya tersebut sering kali memakan banyak korban untuk mencapai keinginannya.

Dalam pandangan Sulasman, ${ }^{21}$ istilah radikalisme sebenarnya bukanlah sesuatu yang asing di dalam ilmu sosial. Berbagai disiplin ilmu yang lain juga sering menggunakan istilah tersebut dalam menjelaskan tentang fenomena-fenomena tertentu. Salah satu contoh, ketika para petani mengadakan penolakan terhadap aturan-aturan yang diberlakukan kepada mereka, kemudian para petani tersebut memprotes keras dan melakukan penolakan secara total seluruh aturan yang diberlakukannya, dengan disertai menggunakan simbol-simbol agama, maka kemudian sejarawan Kartono Kartodijo menyebutnya dengan istilah "radikal".

${ }^{16}$ https://www.vocabulary.com/dictionary/radicalism, diakses 15 September 2016.

${ }_{17}$ http://kbbi.co.id/arti-kata/radikalisme, diakses 15 September 2016

18 Yusuf Qardhawi, Islam Radikal: Analisis terhadap Radikalisme dalam Berislam dan Upaya Pemecahannya, (terj. Hawin Murtadho), (Solo: Era Intermedia, 2004), 23

${ }^{19}$ Mukhibat, "Deradikalisasi dan Integrasi nilai-nilai Pluralitas dalam Kurikulum Pesantren Salafi Haraki di Indonesia", Jurnal al-Tahrir, STAIN Ponorogo, Vol. 14, No. 1 Mei 2014, 187.

${ }^{20}$ Zuly Qodir, "Deradikalisasi Islam dalam Perspektif Pendidikan Agama", Jurnal Pendidikan Islam, UMY, vol. 1, No. 2, Desember 2012, 91.

${ }^{21}$ Sulasman, "Peaceful Jihad dan Pendidikan Deradikalisasi Agama”, Jurnal Walisongo, vol. 23, No. 01, Mei 2015, 153. 
Berdasarkan temuan dari Horace M. Kallen, maka Sulasman kemudian menjelaskan bahwa secara sosilogis, radikalisme dalam gerakannya memiliki tiga karakter utama: yaitu pertama, tindakan radikalisme terjadi akibat respon terhadap kondisi yang ada, respon ini bisa berbentuk kritik, evaluasi dan bisa juga dalam bentuk penolakan secara menyeluruh terhadap kebijakan yang ada. Kedua, gerakan ini bisa jadi tidak hanya sekedar penolakan, tetapi juga adanya upaya-upayauntuk merubah tatanan yang ada dan digantikannya dengan tatanan yang baru. Ketiga, sejalan dengan penolakannya terhadap sistem yang ada, para kaum radikalis berkeyakinan bahwa ide dan gagasan yang dimajukannya tersebut adalah benar dan mampu mengubah kondisi yang ada menjadi lebih baik. ${ }^{22}$

Berdasarkan beberapa pendapat di atas, dapat dipahami bahwa bila dikaitkan dengan sikap keberagamaan, maka radikalisme agama berarti suatu sikap fanatik yang berlebihan terhadap suatu pandangan atau pemahaman mengenai teks atau ajaran agama yang ia yakini sebagai sebuah kebenaran, dengan mengabaikan pendapat-pendapat dan pandangan orang lain tanpa mempertimbangkan kemaslahatan umat. Dengan keyakinannya itu kemudian menganggap orang yang tidak sepaham dengannya dianggapnya menyimpang dari ajaran agama, dianggap kafir dan dimusuhinya. Sebagai sikap pemusuhannya tersebut sering hingga mengancam jiwa manusia lainnya.

\section{Munculnya Paham Radikalisme}

Di dalam Islam, munculnya paham radikalisme tidak bisa dilepaskan dari gerakan Islamisme global yang dipelopori oleh kelompok Ikhwanul Muslimin di Mesir dengan tokohnya Hasan al-Bana dan Abul A`la Al Maududi sebagai pendiri Partai Jamaah Islam yang berada di India. Gagasan-gagasan yang mereka cetuskan tersebut kemudian diperkuat dengan pemikiran-pemikiran Sayyid Qutb melalui karyakaryanya yang menjadikan jihad sebagai sebuah jalan di dalam menegakkan syari at Islam. Ideologiidelogi ini kemudian banyak diikuti dan berkembang ke berbagai wilayah di negeri Islam. ${ }^{23}$

Aliran-aliran tersebut kemudian tumbuh pula di berbagai belahan dunia termasuk di Indonesia. Banyak paham dan gerakan yang beraliran keras berjuang atasnama agama dengan mengusung ideologi jihad sebagai basis perjuangannya. Di Indonesia kita mengenal Gerakan Front Pembela Islam (FPI) yang dipelopori oleh Habib Rizieq Shihab, Laskar Jihad yang dipelopori oleh Jafar Umar Thalib, dan Majelis Mujahidin Indonesia yang dikomandoi oleh Abu Bakar Ba`asyir, dan masih ada beberapa lagi yang lain. ${ }^{24}$ Ada juga organisasi non-kekerasan yang menyuarakan untuk tegaknya khilafah dengan menolak ide-ide negara demokrasi yaitu Hizbut Tahrir Indonesia atau $\mathrm{HTI}^{25}$ yang pertama kali dipelopori oleh Syeikh Taqiyyudin An-Nabhani dari Mesir. Gerakan-gerakan tersebut kemudian berujung dengan keinginan

\footnotetext{
22 Sulasman, "Peaceful Jihad," 153.

${ }^{23}$ Ahmad Darmadji, "Pondok Pesantren dan Deradikalisasi Islam di Indonesia", Jurnal Millah, vol XI, No. 1, Agustus 2011, 236.

24 Mohamad Salik, Negara dan Agama Menelusuri Gagasan Mustafa Kemal dalam Konteks Indonesia (Surabaya: Edufutura Press, 2009), 142-143.

${ }^{25}$ Burhanuddin Muhtadi, Dilema PKS: Suara dan Syariah (Jakarta: KPG Kepustakaan Populer Gramedia, 2012), 2-3.
} 
untuk menegakkan negara Islam dengan membawa ideologi jihad. Berdirinya Negara Islam Irak dan Syiria atau ISIS adalah merupakan bentuk penegasan dari ide menjadikan Islam sebagai ideologi negara dengan melakukan berbagai kekerasan dan diskriminasi atasnama jihad. ${ }^{26}$

Banyak faktor yang menjadi penyebab munculnya paham dan gerakan radikalisme. Dalam hal ini Yusuf Qardhawi menjelaskan dalam sebuah bukunya berjudul Islam Radikal ${ }^{27}$ mengenai sejumlah faktor yang menjadi penyebab munculnya radikalisme, antara lain; 1)pemahaman terhadap ajaran agama yang lemah. 2)Latar belakang pengetahuan berkaitan dengan sejarah, sunnatullah, realitas kehidupan, dan sosial kemasyarakatan yang lemah. 3) Adanya konspirasi dan ancaman-ancaman yang nyata yang mengancam eksistensi umat Islam. Masing-masing faktor tersebut tidaklah berdiri sendiri sebagai faktor tunggal dan paling dominan. Satu dengan yang lain saling berkaitan sehingga menjadi penyebab timbulnya paham dan gerakan-gerakan radikalisme. Dalam istilah lain bahwa munculnya paham dan gerakan radikalisme adalah merupakan sebuah kumpulan berbagai peristiwa yang ada kemudian menimbulkan berbagai macam reaksi tertentu sebagai bentuk perlawanan dan penolakan seperti terorisme, bom bunuh diri, kerusuhan dan berbagai tindak kekerasan lainnya.

Persoalan mengenai timbulnya paham radikalisme di Indonesia, secara historis sebenarnya bukan hanya terjadi pada akhir-akhir ini saja. Jauh pada masa-masa sebelumnya sebenarnya juga pernah terjadi. Pada masa setelah kemerdekaan Republik Indonesia, muncul tokoh-tokoh yang ingin menjadikan Indonesia sebagai negara Islam. Salah satu di antaranya adalah gerakan yang dipimpin oleh SM Kartosuwiryo dengan gagasannya yang dikenal dengan Negara Islam Indonesia atau Darul Islam. Gagasan ini diproklamirkan pada 7 Agustus 1949 tepatnya di Ciawiligar, Tasikmalaya. ${ }^{28}$ Gerakan ini kemudian tumbuh dan berkembang ke berbagai wilayah di Indonesia mulai dari Jawa, Sumatera dan Kalimantan. Namun pada akhirnya gerakan tersebut kemudian bisa diberantas oleh pemerintah pada sekitar tahun 1962.

Ide-ide radikalisme tersebut kemudian muncul kembali seiring dengan bergantinya pemerintahan orde baru dan menyusul munculnya masa kebebasan yang diberikan oleh rezim berikutnya. Suasana kebebasan seperti ini kemudian dimanfaatkan oleh mereka yang hendak menyuarakan ide-ide dan pemikirannya termasuk paham radikal yang berasal dari negeri Timur Tengah. Ketidakmampuan pemerintah Indonesia pada masa itu dalam memberikan kesejahteraan warganya, menyusul ambruknya perekonomian negara demikian pula tingkat korupsi yang semakin merajalela merupakan salah satu dari alasan pemicu munculnya gerakan-gerakan radikal.

Paham dan gerakan-gerakan radikalisme semacam ini tentu sangat membahayakan dan bisa mengancam keutuhan negara apabila tidak dikendalikan. Dalam kaitan dengan hal ini, pemerintah Indonesia telah menyusun program Nasional Kontra Radikal Terorisme yang yangdisebut dengan BNPT

\footnotetext{
${ }^{26}$ Zuhairi Misrawi, “Dialektika Islamisme, Khilafah, dan Syariat”, 69-71.

${ }^{27}$ Yusuf Qardhawi, Islam Radikal, 61-113.

${ }^{28}$ Ahmad Darmadi, "Pondok Pesantren dan Deradikalisasi Islam di Indonesia”, 244.
} 
(Badan Nasional Penanggulangan terorisme). Program ini dibentuk untuk dengan melibatkan berbagai pihak; mulai dari pihak pemerintah sendiri, polisi, aparat keamanan, para tokoh pendidikan, tokoh masyarakat, dan masyarakat sipil dalam upayanya menanggulangi tindakan terorisme. ${ }^{29}$

\section{Pesantren dan Paham Radikalisme}

Istilah "pesantren" berasal dari kata "santri" kemudian mendapatkan awalan "pe" dan akhiran "an". Mengenai istilah "santri" ada beberapa pendapat. Ada yang berpendapat bahwa istilah "santri" berasal dari Bahasa Tamil yang berarti guru ngaji. Ada yang mengatakan bahwa istilah "santri" dari Bahasa India shastri yang berarti orang yang tahu atau ahli kitab suci. ${ }^{30}$ Dalam Bahasa Indonesia, istilah "santri" sering diartikan sebagai seorang murid yang belajar agama pada sebuah pesantren.

Para peneliti secara umum sepakat bahwa pesantren adalah lembaga pendidikan yang berasal dari Indonesia asli. Akan tetapi di antara mereka tidak bersepakat tentang asal usul proses kelahirannya. ${ }^{31}$ Perbedaan pendapat tersebut paling tidak bisa dikelompoknya menjadi dua kelompok besar. Pertama, kelompok yang berpandangan bahwa pesantren adalah merupakan kreasi anak bangsa hasil persentuhan antara tradisi budaya nusantara dengan budaya Islam. Sebagaimana dijelaskan oleh Nurcholish Madjid bahwa sebelumnya juga pernah ada lembaga yang seperti pesantren yaitu ketika masa kekuasaan agama Hindu Budha, kemudian Islam datang melanjutkan lembaga tersebut dengan memberikan sentuhan ajaran-ajaran Islam. ${ }^{32}$ Kedua, kelompok yang berpandangan bahwa pesantren adalah lembaga yang pada mula dipraktekkan di wilayah Timur Tengah kemudian diadopsi oleh masyarakat Islam di Indonesia.

Sebagai sebuah lembaga pendidikan yang asli Indonesia, pesantren di samping menanamkan nilai-nilai keislaman juga menanamkan nilai-nilai keaslian Indonesia dengan menghargai tradisi budayanya. Dalam hal ini Nurcholish Madjid menyatakan bahwa sejak berdirinya, pondok pesantren memiliki karakter dasar 1) tawassut, tidak memihak atau moderasi, 2) Tawazzun, menjaga keseimbangan dan harmoni, 3) Tasamuh, toleransi, 4) Tashawwur, musyawarah, 5) Adl, bersikap adil, melakukan sesuatu sesuai dengan proporsinya. ${ }^{33}$

Melihat dunia pesantren dengan wataknya yang kental dengan nilai-nilai moderasi, harmoni dan toleransi tersebut telah menempatkan para sivitas pesantren sebagai ummatan wasathan (umat yang moderat). Dengan demikian, maka sangat kecil kemungkinan para sivitas pesantren melakukan tindakan-tindakan yang radikal dan anarkhi yang membahayakan orang lain, sebaliknya nilai-nilai,

\footnotetext{
${ }^{29}$ Jely Agri Famela, "Pro dan kontraPelaksanaan Program Deradikalisasi Badan Nasional Penanggulangan Terorisme (BNPT)", Jurnal FISIP UI, 2013, 6-7.

${ }^{30}$ Mohamad Salik, Pembaharuan Pendidikan Pesantren Study atas Gagasan Nurcholish Madjid (Surabaya: IAIN Sunan Ampel Press, 2012), 13.

${ }^{31}$ HM. Amin Haedari, dkk., Masa Depan Pesantren dalam Tantangan Modernitas dan Komplesitas Global (Jakarta, IRD PRESS, 2004), 2.

${ }^{32}$ Nurcholish Madjid, Bilik-bilik Pesantren, Sebuah Potret Perjalanan (Jakarta: Paramadina, 1997), 3.

${ }^{33}$ Yasmadi, Modernisasi Pesantren (Jakarta: Ciputat Press, 2002), 62.
} 
pemikiran dan watak tersebut akan sangat membantu dalam upaya proses menangkal tumbuhnya gerakan-gerakan dan paham radikalisme. ${ }^{34}$

Memang diakui bahwa pada akhir-akhir ini ada beberapa kalangan pesantren yang terlibat dalam tindakan radikalisme. Namun demikian tidak semua pesantren terlibat dalam hal tersebut dan jumlahnya pun sangat sedikit bila dibandingkan dengan jumlah pesantren yang ada. Kalangan pesantren yang terlibat dalam tindakan radikalisme dan pelaku gerakan radikalisme secara umum adalah karena mereka yang telah terpengaruh oleh gerakan Islam transnasional yang kemudian dipicu oleh faktorfaktor lainnya. Faktor-faktor tersebut bisa saja datang dari internal agama itu sendiri seperti kesalahan dalam pemahaman agama, dan bisa juga berasal dari eksternal agama seperti respon terhadap ketidakpuasan terhadap tatanan politik yang ada. Kegagalan pemerintah dalam memberikan jaminan kesejahteraan rakyatnya juga menjadi salah satu pemicu adanya tindakan radikalisme.

Berdasarkan hal di atas, maka pesantren di Indonesia tidak bisa diasosiasikan langsung dengan gerakan-gerakan radikal, apalagi dikaitkan dengan pemikiran Islam radikal yang diusung oleh gerakan transnasional. Hal ini karena pesantren yang adadi Indonesia memiliki karakteristik yang berbeda dibanding dengan lembaga pendidikan Islam yang serupa di wilayah lain. Fakta sejarah menunjukkan bahwa Islam datang ke Indonesia dengan cara damai, penuh keakraban dan tidak melalui jalan peperangan, dan ditambah pula dengan karakter bangsa Indonesia yang sangat menjunjung tinggi nilainilai kesantunan turut mewarnai pemahaman keislaman yang dikembangkan pada pondok pesantren. Karakter-karakter semacam ini turut memengaruhi cara mereka di dalam memahami ajaran Islam, seperti pemahaman terhadap makna jihad tidak selalu bermakna perang sebagaimana yang dipahami oleh kalangan Islam radikal pada umumnya ${ }^{35}$

Berdasarkan hal di atas, maka menangkal pemahaman radikalisme di pesantren, tidak kemudian bermakna bahwa ajaran Islam memiliki watak radikal dan kemudian telah tumbuh pula paham radikal di lembaga pesantren. Menangkal paham radikalisme di pesantren berarti mempertahankan nilai-nilai pesantren yang selama ini telah berkembang baik selaras dengan nilai-nilai ke-Indonesia-an, serta membentengi paham-paham radikal yang datang dari luar yang bisa meruntuhkan nilai-nilai kepesantrenan dan ujungnya akan mengancam keutuhan bangsa.

Banyak cara yang bisa dilakukan oleh kalangan pesantren dalam upaya menangkal tumbuhnya paham radikalisme. Diantaranya bisa dilakukan melalui penguatan institusinya melalui pembenahan kurikulum yang ada yang dirasa sudah kurang relevan dengan perkembangan zaman, mengembangkan model-model pembelajaran yang lebih kreatif dan pembiasaan-pembiasaan karakter yang bisa menumbuhkan sikap kepedulian dan toleransi yang merupakan karakter bangsa Indonesia. Di sisi lain bisa juga dilakukan dengan menambahkan kemampuan ketrampilan-ketrampilan, pemenuhan sarana-

34 Imam Mustofa, Deradikalisasi Ajaran Agama: Urgensi, Problem dan Solusinya, http://ejournal.metrouniv.ac.id/index.php/akademika/article/view/178/255, diakses 14 September 2018.

${ }^{35}$ Ahmad Darmaji, “Pondok Pesantren dan Deradikalisasi Islam di Indonesia”, 246. 
prasarana yang memungkinkan mereka memiliki kreatifitas yang bisa dikembangkan sebagai bekal kehidupannya nanti. Dalam hal ini tentu sebenarnya bukan hanya tugas pengelola pondok pesantren saja, tetapi juga merupakan tugas pemerintah dan anggota masyarakat secara luas. ${ }^{36}$

\section{E. KH. Marzuki Mustamar dan Kiprahnya}

KH Marzuki Mustamar atau yang lebih dikenal dengan Kyai Marzuki dikenal sebagai seorang tokoh NU tinggal di Gasek Malang Jawa Timur. Beliau lahir di Blitar pada 22 September 1966 dari seorang ayah Kyai Mustamar dan Ibu Siti Zainab. Riwayat pendidikannya dimulai dari tingkat dasar hingga SLTA di kota Blitar, kemudian melanjutkan di Perguruan Tinggi di IAIN SunanAmpel di Malang. Semasa kuliah, beliau juga menimbai Imu pada pondok pesantren Nurul Huda Mergosono yang diasuh oleh KH Masduqi Mahfud sebagai RoisSyuriah NU pada waktu itu.

Semasa nyantri di Pondok Pesantren Nurul Huda, KH Marzuki Mustamar tergolong santri yang cukup cerdas melebihi santri yang lainnya. Karena kecerdasannya, beliau sering diminta untuk mengajar pada pondok pesantren tersebut. Beliau juga sering diajak KH Masduqi untuk mendampingi mengisi pengajian dan mengikuti rapat-rapat organisasi kemasyarakatan. Belajar dari gurunya inilah beliau banyak mendapat pengalaman tentang bagaimana mengurus sebuah organisasi kemasyarakatan.

Setelah menikah, beliau mengadu nasib untuk hidup mandiri dengan mengontrak sebuah rumah di wilayah Gasek Sukun Malang. Selang beberapa hari menempati kontrakannya, ternyata telah banyak para santri yang datang untuk mengaji kepada beliau. Seiring berjalannya waktu kemudian beliau berpindah ke sebuah yayasan di wilayah itu yang telah ada sebelumnya. Berawal dari yayasan itulah kemudian Kyai Marzuki bersama masyarakat mengembangkan sebuah pondok Pesantren yang sekarang dikenal dengan Pondok Pesantren Sabilurrosyad Gasek Malang.

Pondok Pesantren tersebut kemudian tumbuh dan berkembang menjadi pesat. Jumlah santri pada pondok pesantren tersebut tidak kurang dari 600 santri yang berasal dari berbagai wilayah di Indonesia. Kebanyakan dari santri tersebut adalah para mahasiswa dari berbagai perguruan tinggi di Malang. Di samping itu dikembangkan pula Pendidikan formal yang meliputi sekolah menengah pertama (SMP) dan sekolah menengah atas (SMA). Kebanyakan para muridnya berasal dari luar daerah. Mereka datang ke pesantren tersebut rata-rata terdorong oleh ketenaran Kyai Marzuki.

KH Marzuki Mustamar dikenal sangat aktif dalam berbagai kepengurusan organisasi kemasyarakatan. Pada Pondok Pesantren Sabilrurrosyad, disamping sebagai pengasuh, beliau juga sekaligus menjadi dewan penasehat pada lembaga tersebut. Beberapa tahun yang lalu beliau pernah menjabat sebagai ketua pengurus cabang NU (PCNU) Kota Malang selama dua periode yaitu pada periode 2011-2016 dan periode sebelumnya, menjadi anggota komisi Fatwa MUI Kota Malang, dan pada

\footnotetext{
${ }^{36}$ Ahmad Darmaji, “Pondok Pesantren dan Deradikalisasi Islam di Indonesia”, 247-248.
} 
periode 2018-2023 beliau terpilih sebagai KetuaTanfidziyah Pengurus Wilayah NU bersama dengan KH Anwar Mansur sebagai Rais Syuriahnya.

Di luar kegiatannya sebagai pengurus organisasi kemasyarakatan, Kyai Marzuki juga memiliki kesibukan yang padat pada kegiatan-kegiatan lainnya. Beliau tercatat sebagai dosen Bahasa Arab pada Fakultas Humaniora UIN Maulana Malik Ibrahim Malang dan pernah menjadi ketua jurusan pada fakultas tersebut. Di samping mengajar beliau juga sering mengisi seminar yang diadakan di berbagai perguruan tinggi dan lembaga-lembaga lainnya. Sebagai seorang mubaligh beliau sering mengisi ceramah-ceramah ke berbagai tempat, mulai dari wilayah Jawa Timur, ke berbagai tempat di Indonesia, dan bahkan pernah beberapa kali diundang mengisi ceramah di luar negeri. Di sela-sela kesibukannya tersebut beliau masih sempat pula menulis karya-karya berbentuk artikel di koran dan buku. Salah satu karyanya yang monumental adalah kitab al-Muqtathafat li ahl al-Bidayat yang berisi sanggahan terhadap kelompok-kelompok terutama salafi Wahabi yang suka membid ahkan sebagian amalan warga nahdhiyin. Buku ini telah dicetak ulang sebanyak sepuluh kali. ${ }^{37}$

\section{F. Menangkal Radikalisme di Pesantren}

Pada bagian ini penulis mengkaji tentang bagaimana gagasan-gagasan KH Marzuki Mustamar dalam upaya menangkal tumbuhnya paham radikalisme pada pondok pesantren. Dalam rangka mencari jawaban tersebut, penulis menggunakan dua jenis data yaitu data primer dan data sekunder. Data primer adalah data yang diambil langsung dari subyek penelitian, dalam hal ini adalah KH. Marzuki Mustamar sebagai satu-satunya subyek dalam penelitian ini. Data ini diperoleh melalui wawancara dengan beliau yang dilakukan secara langsung melalui wawancara yang dilaksanakan pada tanggal 26 September 2019. Adapun data sekunder adalah data yang diambil dari gagasan, pemikiran atau pandangan para tokoh lain berkenaan dengan pokok permasalahan dalam penelitian ini. Gagasan, pandangan atau pemikiran ini diambil dari tulisan-tulisannya baik berupa artikel, buku atau jurnal sebagai pembanding dari gagasan tokoh dalam penelitian ini yaitu KH Marzuki Mustamar.

Berkenaan dengan upaya menangkal paham radikalisme di pesantren, $\mathrm{KH}$ Marzuki Mustamar menjelaskan bahwa kunci utamanya adalah terletak kemampuan para kyai dan para ustadz dalam mengkontekstualisasikan ajaran Islam dengan realitas kehidupan yang ada dalam proses pembelajarannya. Kemampuan inilah yang menjadi factor terpenting dalam upaya menangkal tumbuhnya paham radikalisme di pesantren. Dalam hal ini beliau menyatakan:

"Prinsip utama dalam menangkal radikalisme ya kontekstualisasi, mengajarkan Islam sesuai dengan konteksnya. Karena itu para kyai para ustadz di pesantren harus mampu melakukan hal ini. Dengan kontekstualisasi ini maka tujuan ajaran Islam yaitu kemaslahatan seluruh umat akan benar tercapai. Kitab-kitab yang diajarkan harus ditelaah dengan baik. Apabila ada penafsiranpenafsiran terhadap ajaran agama yang tidak memberikan kemaslahatan atau bertentangan

\footnotetext{
${ }^{37}$ M. Yordanis Salam, "Profil KH Marzuki Mustamar”, https://pwnujatim.or.id/profil-kh-marzuqi-mustamar/, diakses 16
} Maret 2020. 
dengan prinsip kemaslahatan maka perlu dikaji ulang, disesuaikan dengan konteksnya. Itu konsep utama. Para ulama, kyai, ustadz harus mampu melakukan hal itu." ${ }^{38}$

Pernyataan di atas menegaskan bahwa ajaran Islam tidak bisa hanya dipahami secara tekstual saja tetapi perlu melihat di mana konteks ajaran Islam itu dilaksanakan. Tanpa adanya kontekstualisasi, maka kemaslahatan yang menjadi tujuan dari ajaran Islam tidak akan tercapai. Oleh karena itu dalam pandangan beliau, kunci utama keberhasilan dari sebuah pendidikan dalam upaya menangkal radikalisme adalah terletak pada kemampuan para gurunya dalam mengkontekskan ajaran Islam dalam pembelajaran.

Secara lebih rinci KH Marzuki menjelaskan tentang bagaimana strategi-strategi dalam upaya kontekstualisasi ajaran Islam pada pondok pesantren. Mengenai hal ini ada beberapa hal yang harus dilakukan;

1. Memilih kitab-kitab yang berpaham moderat dan menafsirkan ulang terhadap materi yang tidak sesuai dengan konteks Indonesia.

Menurut Kyai Marzuki, paling tidak ada empat kriteria yang harus dipenuhi oleh para ustadz atau kyai dalam memilih materi atau bahan yang hendak diajarkan atau disampaikan kepada para santrinya, yaitu: berbasis ke-NU-an, ahl al Sunnah wa al-Jama `ah, kelndonesiaan dan kemanusiaan. Sebagaimana beliau menyatakan:

"kitab-kitab yang digunakan di pondok sini serupa dengan yang digunakan pada pondok-pondok lain pada umumnya. Dan karena di sini adalah NU maka kitab-kitab yang digunakannya juga yang ber-mainstream NU, ahlus sunnah waljama`ah, ke-Indonesiaan, kemanusiaan. ${ }^{39}$

Bila diamati tampak jelas bahwa empat kriteria di atas merupakan ciri khas dari sebuah pesantren yang berbasis NU. Hal ini bisa dipahami bahwa KH Marzuki memang seorang tokoh NU, tentu pandangan-pandangannya sejalan dengan paham keorganisasiannya. NU sebuah organisasi yang berpaham ahl al sunnah wa al jama 'ah, sebuah paham yang dipandang paling moderat di antara paham-paham yang pernah berkembang. Paham ini berlandaskan pada Al Qur`an, Assunnah, ljma` dan Qiyas. Ciri khas dari paham ini adalah di bidang akidah mengikuti paham yang dipelopori oleh Abu al Hasan al Asy`ari dan Abu Mansur Muhammad al Maturidi, di bidang fikh mengikuti salah satu dari empat madzhab, namun dalam praktiknya kebanyakan hanya mengikuti satu madzhab yaitu Imam Syafi i, di bidang tasawuf mereka mengikuti ajaran yang dibawa oleh al-Junaid al-Baghdadi dan Imam al-Ghazali..$^{40} \mathrm{Di}$ samping mendasarkan pemahamannya pada empat hal di atas, pemahaman kalangan NU mengenai ahl al sunnah juga disesuaikan dengan kultur atau budaya yang ada di

\footnotetext{
${ }^{38} \mathrm{KH}$. Marzuki Mustamar, wawancara pada 26 September 2019.

${ }^{39} \mathrm{KH}$. Marzuki, wawancara.

${ }^{40}$ Mohamad Salik, "Conserving Moderate Islam in Indonesia An Analysis of Muwafiq`s Speech on Online Media", "Journal of Indonesian Islam, Vol. 13 No. 02 (June 2019); 376. Lihat pula Ahmad Zahro, Tradisi intelektual NU: Lajnah Bahtsul Masa il 1926-1999 (Yogyakarta: LKiS, 2004), 19.
} 
Indonesia. Ini menunjukkan bahwa kitab-kitab atau referensi yang diajarkan pada pondok pesantren harus berpaham Ahlussunnah dan tidak bertentangan dengan kultur ke-Indonesiaan. ${ }^{41}$

Namun demikian, tidak semua kitab-kitab yang berpaham ahl al sunnah bisa langsung digunakan sebagai referensi atau buku rujukan dalam pembelajaran di pesantren, terutama berkaitan dengan masalah sosial dan politik. Hal ini sebagaimana dinyatakan oleh KH Marzuki:

"Namun demikian walaupun ahlussunnah kalau settingannya adalah Timur Tengah tentu harus ditelaah dulu. Apalagi kitab-kitab yang menyangkut ilmu-ilmu sosial, budaya, ketatanegaraan dan semacamnya, sekalipun settinganya ahlussunnah, maka harus dimodifikasi dulu, di assembling, tidak boleh secara mentah diterimanya. Kitab-kitab seperti ahkamu al-Sulthoniyah karangan Imam Mawardi, kitabnya IbnuTaimiyah, maka harus dikontekskan dulu dalam konteks ke-Indonesiaan. Seperti tentang perlu tidaknya mendirikan Islam, menegakkan syariat Islam di bumi Indonesia, dan seterusnya, perlu dilihat konteksnya dulu dengan konteks Indonesia." 42

Karya-karya sebagaimana yang disebut di atas lebih banyak berkaitan dengan masalah siyasah atau politik. Kitab al Ahkam al-Sulthoniyah, sebagai missal yang ditulis oleh Imam alMawardi, ${ }^{43}$ di dalamnya ditulis mengenai prinsip-prinsip dan kewajiban mendirikan dan menegakkan negara Islam, kitab Siyasah al Syariyah karya IbnuTaimiyah ${ }^{44}$ yang juga membahas tentang konsep politik dalam Islam. Kitab Fath al Qarib dan Fath al Mu in dalam salah satu babnya juga membahas tentang pentingnya mendirikan negara dan menegakkan syari’at Islam. Kitab-kitab tersebut ketika diajarkan pada pondok pesantren tentu harus disesuaikan dengan konteks yang ada di Indonesia. Hal ini karena konteks di mana para pengarangnya menulis dengan konteks di Indonesia sangat berbeda.

2. Menanamkan nilai-nilai ketauhidan dan kemanusiaan secara seimbang.

Ada dua nilai yang mutlak harus ditanamkan oleh para kyai, para ustadz kepada para santri, yaitu nilai ketauhidan dan nilai kemanusiaan. Nilai tauhid adalah nilai-nilai berkaitan dengan hubungan antara hamba dengan penciptanya (hablun min-Allah), sedangkan nilai kemanusiaan adalah nilai-nilai yang berkaitan dengan hubungan antara manusia dengan sesamanya. Dalam pandangan KH Marzuki, kedua nilai tersebut harus ditanamkan kepada para santri dan harus diamalkan agar bisa terwujud keseimbangan dan keharmonisan dalam kehidupanya itu manusia yang berketuhanan dan manusia yang berkemanusiaan.

\footnotetext{
${ }^{41}$ Mohamad Salik, Nahdlatul Ulama dan Gagasan Moderasi Islam (Malang: Edulitera, 2020), 77

42 KH Marzuki, Wawancara.

${ }^{43}$ Imam al Mawardi hidup antara tahun $975 \mathrm{M}$ dan $1059 \mathrm{M}$. Beliau adalah seorang pemikir Islam terkemuka bermadzhab Syafi i dan pejabat tinggi yang besar pengaruhnya dalam pemerintahan Abbasiyah. Setelah berpindah-pindah dari satu kota ke kota lain sebagai hakim, akhirnya beliau kembali dan menetap di Baghdad, dan mendapatkan kedudukan terhormat pada pemerintahan Khalifah Qadir. Kitab al-ahkam al sulthaniyah merupakan karyanya yang paling terkenal di bidang politik dan telah dicetak berkali-kali di Mesir dan diterjemahkan ke dalam berbagai Bahasa. Lihat Munawir Sjadzali, Islam dan Tata Negara, (Jakarta: UI-Press, 1994), 58.

${ }^{44}$ Ibnu Taimiyah lahir di Haran dekat Damascus, Suria tahun 1263M, pada masa-masa berakhirnya Dinasti Abbasiyah. Beliau dikenal sebagai ilmuwan yang berwawasan luas, menguasai berbagai cabang ilmu pengetahuan; tafsir, Hadits, teologi, politik dan fikh khususnya fikh Hambali. Salah satu karyanya yang terkenal di bidang politik adalah Al-Siyash alSyar iyah fi islah al-Ra `wa al-Ra ìyah. Munawir Sjadzali, Islam dan Tata Negara, 79,82.
} 
Menurut KH Marzuki, Kedua nilai di atas tidak akan bisa terwujud dalam kehidupan apabila tidak dilindungi oleh negara yang mengaturnya. Oleh karena itu perlu ditanamkan kepada para santri tentang pentingnya ikut menjaga keamanan dan keutuhan negara. Karena hal tersebut adalah merupakan bagian dari kewajiban beragama. Tidak boleh menghadap-hadapkan apalagi mempertentangkan antara negara dan agama, hanya membela agamanya sementara kewajiban bernegara diabaikan ataupun sebaliknya membela negara sementara kewajiban terhadap agamanya diabaikan. ${ }^{45}$

Dalam pandangan KH Marzuki, ajaran Islam tidak bertentangan dengan nilai-nilai Pancasila, karena konteksnya adalah di Indonesia. Karena kenyataan memang tidak mungkin menjadikan Islam sebagai dasar negara Republik Indonesia dengan melihat penduduk Indonesia terdiri dari berbagai macam agama yang dipeluknya. Kesepakatan para pendiri bangsa yang telah menjadikan Pancasila sebagai dasar berbangsa sudah selayaknya untuk didukung agar persatuan bangsa bisa terwujud. Bagi umat Islam yang misi utamanya adalah perdamaian tentu merupakan kewajiban untuk mengamalkannya. Kekonsistenan umat Islam untuk mengamalkan Pancasila pada ujungnya juga akan kembali kepada kebaikan umat Islam itu sendiri. Hal ini sesuai dengan pernyataan beliau:

Jadi umat Islam itu harus mengamalkan sila pertama, kedua dan ketiga dan harus bareng. Dengan bahasa yang sederhana negara yang melindungi, isinya adalah dua nilai besar tersebut; yaitu ketuhanan (tauhid) dan berkemanusiaan. Ketika orang-orang beragama itu melakukan hal-hal yang beradab, maka agama itu akan semakin diterima oleh masyarakat, dan yang akan beruntung juga orang agama itu sendiri. Supaya utuh lestari, maka kita tidak boleh semenamena, kita harus sadar bahwa ini adalah negaranya orang banyak, banyak kepentingan, makanya semuanya harus diselesaikan dengan bermusyawarah (sila keempat), biar kesemuanya tidak ada yang dirugikan, senang susah ditanggung bersama. Apabila keempatnya bisa dilakukan maka bangsa Indonesia akan mengenyam keadilan (sila ke lima), baldatun toyyibatun warobbun Ghofur. Jadi intinya demikian, yaitu seimbang keduanya harus berjalan bersama-sama, Islamnya lestari, kemanusiaannya lestari, Indonesianya lestari. Ini yang harus kita patrikan kepada semua umat Islam, kepada para santri kita utamanya sebagai pewaris dan penerus bangsa ini di masa yang akan datang. ${ }^{46}$

3. Keteladanan

Dalam pandangan KH Marzuki, kontekstualisasi ajaran Islam, tidak cukup hanya diucapkan atau disampaikan saja. Sebagai seorang kyai atau seorang ustadz harus mampu memerankan diri sebagai teladan di tengah-tengah masyarakat tentang bagaimana seharusnya berperilaku baik berkaitan dengan hubungan kepada Allah maupun hubungan kepada sesama manusia. Dalam hal ini $\mathrm{KH}$. Marzuki menjelaskan:

Sebagai kyai, pengasuh pesantren harus mampu menjadi teladan bagi para santrinya dan masyarakatnya, harus mampu mencontohkan bagaimana ajaran Islam ini harus diterapkan tengah-tengah kehidupan yang nyata. Seperti yang sudah dicontohkan oleh Nabi. Nabi adalah orang yang paling berkemanusiaan, paling bertauhid, dan paling cinta tanah air, orang yang paling toleran. Bahkan beliau bersabda; "orang yang menyakiti orang kafir dzimmi sama

\footnotetext{
${ }^{45} \mathrm{KH}$ Marzuki, wawancara.
}

${ }^{46} \mathrm{KH}$ Marzuki, wawancara. 
dengan menyakiti saya. "Perjanjian dengan non-muslim harus ditepati, jangan gara-gara mereka non-muslim kemudian kita khianati. Hal ini tidak boleh. Nabi pernah mempersilakan orang non-muslim tinggal di rumahnya, harapannya siapa tahu dengan demikian dia akan terbuka hatinya mengikuti ajaran kita setelah melihat sikap kita kemudian mendapatkan hidayah. Ini harus ditanamkan kepada para santri, yaitu melalui keteladanan para ustadznya. Kalau dulu, Ketika Nabi masih sugeng, beliau sendiri yang menjadi teladannya, dan sekarang harus diwarisi oleh para kyai para ustadz supaya bisa diteladani oleh para santrinya. ${ }^{47}$

Berdasarkan pernyataan di atas secara jelas menegaskan bahwa sebagai seorang kyai atau ustadz maka mereka harus mampu menjadi panutan baik dalam berperilaku berkaitan dengan hubungannya terhadap Allah maupun terhadap sesame manusia dengan mencontoh perilaku sebagaimana yang telah diterapkan oleh Nabi Muhammad Saw., dekat kepada Allah sekaligus memiliki rasa kemanusiaan yang tinggi.

Satu hal lagi yang harus diperankan oleh para kyai adalah mereka harus bisa memberi contoh bagaimana sebagai seorang Muslim menjadi warga negara yang baik dan cinta terhadap negara dan bangsanya. Sebagaimana KH Marzuki menyatakan:

Sebagai seorang kyai juga harus memiliki nasionalisme yang tinggi sebagaimana juga Nabi. Beliau sangat cinta terhadap tanah air dan bangsanya. Begitu cintanya kepada tanah kelahirannya, mau meninggalkan tanah kelahirannya Mekah beliau seakan menangis, Beliau bersabda "Wahai Mekah, engkau adalah negeri yang paling aku cintai, andai aku tidak diusir oleh orang-orang kafir, maka aku tidak akan meninggalkanmu"48

Sifat-sifat seperti di atas harus dimiliki oleh para ulama, para kyai dan para pengasuh pesantren agar bisa dicontoh oleh para santrinya. Karena hal ini sangat penting dalam membentuk karakter para santri. Bagaimana model dan karakter santrinya pada sebuah lembaga pesantren, sangatlah bergantung pada keteladanan yang dicontohkan kyai kepada para santrinya. Sebagaimana dinyatakan oleh KH Marzuki:

"Sebagai seorang ustadz atau kyai, maka mereka harus mampu menjadi teladan bagi para santrinya, sebagaimana pula Nabi menjadi teladan bagi umatnya. Para santri yang mondok, tentu akan mengetahui apa saja yang dilakukan oleh kyainya oleh ustadznya, mereka mengamati dan akhirnya mereka akan mencontohnya mulai dari bagaimana kyai harus membimbing keluarganya, berkiprah di masyarakat dan sebagainya. Karena itu seorang kyai harus tampil sebagai teladan di tengah-tengah para santrinya." ${ }^{\prime 49}$

4. Pentingnya Pembiasaan

Strategi penting lainnya dalam upaya kontekstualisasi ajaran Islam di pesantren adalah dengan cara pembiasaan. Menurut KH Marzuki, sejak awal mulai masuk ke pesantren, anak-anak sudah dilatih untuk hidup sebagaimana dalam kehidupan yang nyata di masyarakat. Mereka dibiasakan untuk berbaur dalam kegiatan-kegiatan di masyarakat. Kegiatan ini adalah penting agar

\footnotetext{
${ }^{47} \mathrm{KH}$ Marzuki, wawancara.

${ }^{48} \mathrm{KH}$ Marzuki, wawancara.

${ }^{49} \mathrm{KH}$ Marzuki, wawancara.
} 
para santri berlatih untuk berinteraksi langsung dengan masyarakat, tahu seluk beluk yang ada di masyarakat, bisa saling tukar pikiran dengan anggota masyarakat, yang pada akhirnya diharapkan mereka mampu mendialogkan antara nilai-nilai ajaran yang diperolehnya di pesantren dengan kenyataan yang ada di masyarakat. Hal ini sebagaimana dinyatakan oleh KH Marzuki:

"Untuk menerapkan ajaran Islam yang santun, toleran kepada santri, mereka kita suruh berlatih berbaur dengan masyarakat. Makanya di sini ada kegiatan-kegiatan yang bersentuhan langsung dengan masyarakat, seperti diba `an, yasinan, tahlilan yang diadakan oleh masyarakat, santri kita suruh untuk ikut berbaur di sana, setiap minggu juga ada kerja bakti di masyarakat, istighosah, anak-anak saya suruh ikut terlibat di situ. Itu manfaatnya besar biar anak-anak tahu keadaan lingkungan masyarakat, cara pandang masyarakat. Terus dari ilmu yang diperolehnya itu kemudian biar mereka mencoba mengait-kaitkan dengan kondisi lingkungan yang dia temui." 50

Di lingkungan pesantren, pembiasaan-pembiasaan yang baik ini tidak hanya berlaku dengan sesama santri atau dengan masyarakat Muslim sekitarnya saja, tetapi bahkan dengan orang-orang non-Muslim sekalipun. Mereka juga belajar bagaimana menjalin hubungan baik dengan mereka, bersama-sama dalam kegiatan sosial dan bahkan saling membantu di dalam kegiatan-kegiatan tertentu. Dengan cara demikian maka diharapkan para non-Muslim menjadi semakin simpatik dengan kebaikan yang kita berikan. Sebagaimana dinyatakan oleh KH Marzuki:

"Kita sering mengadakan lomba-lomba dengan masyarakat, kita juga sering mengikuti lomba di masyarakat, bahkan kita juga pernah ikut lomba futsal yang diadakan oleh orang-orang Kristen di kampung sebelah. Kita juga sering menyuruh anak-anak menjadi banser, ikut menjaga keamanan waktu mereka ada kegiatan keagamaan. Kita sering melakukan itu. Nanti untungnya juga akan kembali kepada kita. Mereka akan tahu kalau orang Muslim itu baik. Nanti kalau pas kita ada kegiatan gentian mereka akan melakukan begitu juga kepada kita, atau minimal mereka tidak akan ngrusuhi."51

Kegiatan lain yang perlu dibiasakan pula adalah melakukan kegiatan-kegiatan semacam seremonial kebangsaan dalam upaya memperteguh kesetiaan kepada bangsa. Kegiatan-kegiatan tersebut seperti upacara 17 Agustus, karnaval, istighosah, kegiatan doa bersama dalam rangka mendoakan keselamatan bangsa dan lain sebagainya adalah penting untuk dilakukan untuk menambah kecintaan kepada bangsanya. Dengan demikian diharapkan kita semua menjadi semakin sadar bahwa negara ini milik kita bersama yang wajib kita jaga secara bersama-sama dan sebagai bentuk rasa terima kasih kita atas pengorbanan para pahlawan yang telah memperjuangkan kemerdekaan negeri ini. Bagi para santri, mengenang kemerdekaan berarti mengenang para tokoh ulama yang telah dengan rela mengorbankan jiwa dan raganya demi kemerdekaan bangsa dan telah meninggalkan banyak jasa-jasanya demi tegaknya Islam di bumi nusantara ini. Sebagaimana dinyatakan oleh KH Marzuki:

\footnotetext{
${ }^{50} \mathrm{KH}$ Marzuki, wawancara.

${ }^{51} \mathrm{KH}$ Marzuki, wawancara.
} 
"Upacara itu untuk menyadarkan rakyat dan umat bahwa negara bukan milik pejabat, tapi milik semua saja. Jadi yang harus mensyukuri jangan mereka saja, tapi kita juga. Kalau rakyat merasa memiliki, maka kewajiban menjaga negara rakyat sadar, maka pertahanan negara sangat kokoh. Tidak harus TNI saja. Dulu yang perang juga ulama, Pangeran Diponegoro, Jendral Sudirman, Cokroaminoto, KH Agus Salim, KH Hasyim Asy'ari. Kalau kita santri, wajib melestarikan tinggalannya ulama, kitab kuning, pesantren dilestarikan karena tingalannya ulama. RI juga wajib dilestarikan karena warisan para ulama." ${ }^{52}$

\section{G. Diskusi}

Berdasarkan temuan sebagaimana telah dipaparkan di atas, ada catatan penting yang kiranya perlu untuk didiskusikan lebih lanjut, yaitu bahwa dalam pandangan KH Marzuki upaya menangkal tumbuhnya paham radikalisme pada pesantren diperlukan upaya kontekstualisasi atas pemahaman terhadap ajaran-ajaran Islam. Kontekstualisasi tersebut dilakukan dengan cara; pertama, menyesuaikan materi-materi ajar atau kitab-kitab yang diajarkannya berdasarkan konteks yang ada di Indonesia, kedua, menanamkan nilai-nilai ketauhidan dan nilai-nilai kemanusiaan secara seimbang, ketiga memberikan teladan secara nyata dalam kehidupan mengenai perilaku-perilaku sebagai wujud kontekstualisasi nilai ajaran Islam, keempat, membiasakan para santri hidup bermasyarakat dalam keragaman dengan toleransi.

Gagasan KH Marzuki tentang pentingnya kontekstualisasi ajaran Islam ini memperkuat pandangan umumnya para tokoh Muslim pluralis Indonesia sebelumnya. Nurcholish Madjid sebagai misal menyatakan bahwa agar ajaran-ajaran Islam bisa eksis, maka perlu disesuaikan dengan konteks di mana ajaran Islam itu tumbuh dan diimplementasikan. Dalam pandangan beliau, meskipun pada dasarnya ajaran-ajaran Islam itu sifatnya universal, namun dalam implementasinya mengharuskan kita untuk mengetahui kondisi sosial budaya dan politik yang ada pada masyarakat Indonesia secara keseluruhan dalam kerangka konsep bernegara dan berbangsa. Fakta bahwa Indonesia merupakan negara dengan tingkat pluralitas yang tinggi baik dari segi tradisi budaya dan bahkan agama, dalam pandangan Nurcholish Madjid bukan saja harus kita terima apa adanya, tetapi juga harus selalu kita perhitungkan. Berkaitan dengan hal tersebut, maka apapun langkah yang kita lakukan dalam mengimplementasikan ajaran Islam harus selalu memperhitungkan situasi dan kondisi masyarakat baik dari segi sosial dan budayanya sebagai cirri dari perkembangan dan keragaman. ${ }^{53}$

Pandangan serupa juga diungkapkan oleh KH Hasyim Muzadi bahwa ajaran Islam tidak turun di ruang hampa, tetapi pada sebuah masyarakat di mana pada masyarakat tersebut telah tumbuh budayanya masing-masing. Karena itu sudah barang tentu penafsiran-penafsiran terhadap ajaran Islam dipengaruhi oleh latar belakang sosial-budayanya. ${ }^{54}$ Ketika Islam turun di Arab, tentu penafsiran-

\footnotetext{
52 KH Marzuki, wawancara.

53 M. Syafi i Anwar, "Sosiologi Pembaruan Pemikiran Islam Nurcholish Madjid, Jurnal Ulumul Qur'an, Vol. 04, No. 01, (1993), 20-22.

${ }^{54}$ KH Hasyim Muzadi, Nahdlatul Ulama di tengah Agenda Persoalan Bangsa (Ciputat: PT Logos Wacana IImu, 1999), 114-115.
} 
penafsiran terhadap ajaran Islam dipengaruhi oleh konteks Arab. Oleh karena itu merupakan sebuah keniscayaan, ketika Islam masuk ke Indonesia, penafsiran terhadap ajaran-ajaran Islam menyesuaikan dengan konteks yang ada di Indonesia. Ketidakmampuan umat Islam mengontekstualisasikan ajaran Islam dengan kondisi masyarakatnya, akan berakibat Islam tidak memberikan kemaslahatan dan bahkan kontradiktif dengan tujuan diturunkannya ajaran Islam itu sendiri. ${ }^{55}$ Paham-paham dan gerakan radikal yang berujung pada tindakan-tindakan terorisme jelas bertentangan dengan tujuan diturunkannya syariat Islam yaitu sebagai rahmatan lil 'alamin.

Dalam upaya perlunya kontektualisasi ajaran Islam, Gus Dur juga pernah melontarkan sebuah gagasan yang dikenal dengan "pribumisasi Islam." Gagasan ini dilontarkan dalam upaya membendung keinginan sebagian Islam yang menghendaki wajah Islam di Indonesia sama sebagaimana yang ada di Arab atau yang dikenal dengan istilah Arabisasi. Gagasan Pribumisasi Islam menghendaki agar Islam dengan budaya tidak saling mengalahkan tetapi berusaha untuk mempertemukan antara keduanya. Karena gerakan Arabisasi yang diusung oleh kelompok keras sangat membahayakan bagi keutuhan bangsa dan bahkan bisa menyebabkan tecerabutnya bangsa Indonesia dari akar budayanya. ${ }^{56}$

\section{H. Kesimpulan}

Berdasarkan paparan di atas paling tidak ada dua hal penting yang perlu dikemukakan di sini berkaitan dengan upaya menangkal tumbuhnya paham radikalisme di pondok pesantren. Pertama, perlunya menyadari bahwa pada realitasnya Islam diturunkan di negeri Arab yang secara otomatis penafsiran-penafsirannya mengenai ajaran Islam dipengaruhi oleh situasi dan kondisi di negeri Arab. Ketika ajaran Islam sampai ke Indonesia, merupakan keniscayaan ketika ajaran Islam harus disesuaikan dengan konteks Indonesia agar tujuan diturunkannya syari at Islam tercapai yaitu untuk kemaslahatan seluruh umat. Kedua, Pesantren sebagai sebuah lembaga pendidikan Islam yang dikenal toleran, kontekstualisasi terhadap ajaran-ajaran Islam merupakan strategi yang sangat tepat dalam rangka menjadikan ajaran-ajaran Islam selalu sejalan dengan perkembangan situasi zamannya. Upaya kontekstualisasi ajaran Islam bagi para pengasuh pesantren tidak hanya dengan menyelaraskan materimateri pembelajaran berdasarkan konteksnya, tetapi juga perlu dilakukan melalui keteladanan dan pembiasaan.

\section{Referensi}

Asy`ari, Musa,Menggagas Revolusi Kebudayaan tanpa Kekerasan, Yogyakarta: LESFI, 2003.

Bruinessen, Martin van, The Madrasa in Asia Political Activism and Transnational Linkages, Amsterdam: University Press, 2008.

Darmadji, Ahmad, "Pondok Pesantren dan Deradikalisasi Islam di Indonesia”, Jurnal Millah, vol XI, No. 1, Agustus 2011.

\footnotetext{
${ }^{55}$ Mohamad Salik, Nahdlatul Ulama dan GagasanModerasi Islam, 88-89.

${ }^{56}$ Abdurrahman Wahid, Pergulatan Negara, Agama dan Kebudayaan (Jakarta: Desantara, 2001), 111.
} 
Famela, Jely Agri, "Pro dan kontra Pelaksanaan Program Deradikalisasi Badan Nasional Penanggulangan Terorisme (BNPT), Jurnal FISIP UI, 2013.

Farikh, Amir "Konsistensi Nahdhatul Ulama dalam Mempertahankan Pancasila dan Kedaulatan Negara Kesatuan Republik Indonesia di Tengah Wacana Negara Islam", JPW Vol. 1 No. 1, 2019.

Haedari HM. Amin dkk, Masa Depan Pesantren dalam Tantangan Modernitas dan Komplesitas Global, Jakarta: IRD PRESS, 2004.

Hefner, Robert W., Making Modern Muslims; The Politics of Islamic Education in Southeast Asia, University of Hawaii Press, 2009.

Hornby, AS, Oxford Advanced Dictionary of Current English, London: Oxford University Press, 1974.

Madjid, Nurcholish, Bilik-bilik Pesantren, Sebuah Potret Perjalanan, Jakarta: Paramadina, 1997.

Mas`ud, Abd Rahman, "Peran Ulama dalam Menjaga Persatuan, Kesatuan, dan Keutuhan NKRI" sambutan atasnama Menteri Agama di Pondok Pesantren Al-Hikam, Depok (11/6). http://www.kemenag.go.id/index.php?a=berita\&id=267512, diakses 26 Maret 2016.

Misrawi, Zuhairi, "Dialektika Islamisme, Khilafah dan Syari’ah," dalam Komaruddin Hidayat (ed), Kontroversi Khilafah Islam, Negara dan Pancasila, Bandung: Mizan, 2014.

Muhtadi, Burhanuddin, Dilema PKS: Suara dan Syariah. Jakarta: KPG Kepustakaan Populer Gramedia, 2012.

Mukhibat, "Deradikalisasi dan Integrasi Nilai-nilai Pluralitas dalam Kurikulum Pesantren Salafi Haraki di Indonesia, Jurnal Al Tahrir, Vol. IV, No. 1, Mei 2014.

Mustamar, Marzuki, Wawancara pada 26 September 2019.

Natsir, M, Agama dan negara dalam Perspektif Islam, Jakarta: Media Dakwah, 2001.

Purnomo, Agus, Ideologi Kekerasan; Argumentasi Teologis-Sosial Radikalisme Islam, Yogyakarta: Pustaka pelajar, 2009.

Qardhawi, Yusuf, Islam Radikal: Analisis terhadap Radikalisme dalam Berislam dan Upaya Pemecahannya, (terj. Hawin Murtadho), Solo: Era Intermedia, 2004.

Qodir, Zuly, "Deradikalisasi Islam dalam Perspektif Pendidikan Agama", Jurnal Pendidikan Islam, UMY, vol. 1, No. 2, Desember 2012.

Ramadhan, Muammar, "Deradikalisasi Agama melalui Pendidikan Multikultural dan Inklusivisme (Studi pada Pesantren al Hikmah Benda Sirampog Brebes), Smart, Vol. 01, No. 02 Desember 2015.

Salam, M. Yordanis "Profil KH Marzuki Mustamar", https://pwnujatim.or.id/profil-kh-marzuqimustamar/, diakses 16 Maret 2020.

Salik, Mohamad, "Conserving Moderate Islam in Indonesia An Analysis of Muwafiq's Speech on Online Media", Journal of Indonesian Islam, Vol. 13 No. 02, June 2019. Negara dan Agama Menelusuri Gagasan Mustafa Kemal dalam Konteks Indonesia, Surabaya: Edufutura Press, 2009.

Pembaharuan Pendidikan Pesantren Study atas Gagasan Nurcholish Madjid, Surabaya: IAIN Sunan Ampel Press, 2012.

, Nahdlatul Ulama dan Gagasan Moderasi Islam, Malang: Edulitera, 2020.

Sulasman, "Peaceful Jihad dan Pendidikan Deradikalisasi Agama," Jurnal Walisongo, Vol. XXIII, No. 1, Mei 2015.

Sjadzali, Munawir, Islam dan Tata Negara, Jakarta: UI-Press, 1994.

Tafsir, Ahmad, Ilmu Pendidikan dalam Perspektif Islam, Bandung: RemajaRosdakarya, 1991.

Wahid, Abdurrahman, Pergulatan Negara, Agama dan Kebudayaan, Jakarta:Desantara, 2001.

Yasmadi, Modernisasi Pesantren, Jakarta: Ciputat Press, 2002. 
Mohamad Salik \& Ali Mas'ud

Zahro, Ahmad, Tradisi intelektual NU: Lajnah Bahtsul Masa il 1926-1999, Yogyakarta: LKiS, 2004. 